\title{
REKONSILIASI ANTARA ISLAM DAN LOCAL WISDOM DALAM KONTEKSTUALISASI HADĪTH TENTANG LARANGAN TASHABBUH
}

\author{
Sulaemang L \\ Institut Agama Islam Negeri Kendari, Indonesia \\ E-mail: sulaemang@iainkendari.ac.id
}

Nur Hadi

Institut Islam Mamba'ul Ulum Surakarta, Indonesia

E-mail: nurhaditalang78@gmail.com

\author{
Abdul Muiz Amir \\ Institut Agama Islam Negeri Kendari, Indonesia \\ E-mail: abdulmuiz@iainkendari.ac.id
}

\begin{abstract}
This article focuses on the study of the contextualization of the meaning of the hadith about tashabbuh using both macro and micro socio-historical study approach. The study was conducted to find the significance of the meaning contained in the hadith about the prohibition of tashabbuh, using the study of hadith literature and historical sources. The results of the study found that; (1) the study of the hadith about prohibition of tashabbuh cannot be understood by only using a textualliteral approach, because it can only narrow down the meaning of hadith, so it is more likely to lead to a fundamentalist-radicalist understanding; (2) Studying the hadiths is to find the meaning behind the text, context, and contextualization of the hadith, theologically normative aims to maintain the faith dan the belief in tawhid, while socially cultural aims to relize the Islamic foundation as tolerance and rahmah; (3) there are two types of tashabbuh in the theological-normative domain; showing absolute prohibition, and social welfare; showing skill as long as it does not conflict with the basic rules of shari'ah and realizes maslahat for human life.
\end{abstract}

Keywords: Reconsiliation; tashabbuh; contextualization; local wisdom. 


\section{Pendahuluan}

Bila ditinjau secara sosiologis, manusia merupakan makhluk sosial yang juga memiliki kecenderungan untuk mengadopsi segala sesuatu yang dianggap memiki keunikan dan ketertarikan. Hal itu mereka lakukan guna membentuk diri dalam bersosialisasi dan beradaptasi dengan lingkungan masyarakat yang dihadapinya. Kecenderungan tersebut dapat dilihat sejak manusia masih berada dalam masa kanak-kanak yang mencoba untuk meniru perilaku orang tuanya dan orang-orang yang ada di sekitarnya; imigran yang mencoba meniru tradisi atau budaya pribumi atau sebaliknya, masyarakat tradisional (pedesaan) yang meniru modernitas masyarakat modern (perkotaan), fans yang meniru figurnya, dan lain sebagainya. Kecenderungan itu merupakan fitrah manusia sebagai bentuk perkembangan fisik dan pola pikir untuk lebih maju. ${ }^{1}$

Secara historis, Islam datang tidak serta merta membawa ajaran baru yang tidak dikenal oleh masyarakat kala itu, melainkan terdapat beberapa tradisi yang diadopsi sebelumnya untuk ditanamkan nilai-nila kemanusiaan yang luhur dan bernuansa spritual, sehingga Agama Islam hadir bukan hanya mencakup ajaran akidah teologi normatif (tauhid), melainkan di dalamnya juga mencakup ajaran muamalah (bersosialisasi dan bermasyarakat). Ini sebagai bentuk agama yang peduli terhadap kemanusiaan sekaligus memberikan porsi yang seimbang untuk kehidupan dunia dan akhirat. Inilah sebabnya mengapa Islam dikenal sebagai agama yang mengedepankan konsep ajaran rạ̣mah li al-älamin. Bagi Rasulullah, hal itu bukan sekedar slogan dan iklan semata, melainkan yang demikian itu langsung dipraktekkan dalam kehidupan sehari-hari. Maka tidak heran bila Rasulullah dikenal sebagai manusia yang memiliki akhlak mulia, bukan hanya panutan dalam menjalankan ibadah ritual, melainkan juga menjadi tauladan dalam bermasyarakat. Hal ini sebagaimana jawaban 'Aishah, ketika ditanya tentang perilaku Rasulullah: "kāna khuluquh al-Qur'ān" (akhlak Rasulullah adalah cerminan ajaran al-Qur'ān).

Sudah menjadi kewajiban seorang Muslim untuk meneladani akhlak Rasulullah, yang oleh umat Islam disebut dengan istilah

1 Rusmin Tumanggor, et al., Ilmu Sosial dan Budaya Dasar (Jakarta: Kencana, 2010), 56.

2 Sulaymān b. Aḥmad b. Ayyūb al-Ṭabrānī, Al-Mưjam al-Awsat, ed. Ṭarīq b.

'Awdhillāh b. Muḥammad, Vol. 1 (Kairo: Dār al-Ḥaramayn, t.th.), 30. 
"ittibā' sunnat al-nabl”, dengan cara mengikuti sunnahnya. Tetapi pada dasarnya Sunnah Rasulullah, meliputi tiga aspek; (1) Sunnah Sirab; ${ }^{3}$ (3) Sunnah Sürab; ${ }^{4}$ (3) Sunnab Sarirah. ${ }^{5}$ Namun, terdapat fenomena baru di kalangan umat Islam pada era (kekinian), dengan menunjukkan penampilan atau berpakaian "ke-Arab-an", memelihara jenggot, menggunakan celana cingkrang dengan dalih hijrah yang merupakan manifestasi bentuk pelaksanaan Sunnah Nabi, sehingga orang-orang (Muslim) yang berpakaian tidak sesuai selera mereka dianggap tashabbuh (menyerupai orang kafir) dan tidak menjalankan Sunnah Nabi. Namun di sisi lain, tutur kata mereka kerap kali menyakiti hati orang lain (orang-orang yang dianggap mushabbih), bahkan menggunakan perilaku kekerasan fisik yang kerap kali mereka lakukan dengan dalih menegakkan amar makruf dan nahi munkar.

Selain itu, pemahaman yang demikian dipengaruhi oleh kajiankajian sejarah klasik yang seolah ingin dipaksakan untuk ditarik dan kemudian diterapkan di masa kini yang tentu saja memiliki perbedaan konteks yang amat jauh. Cara tersebut, dapat menimbulkan mudarat yang lebih besar, bahkan dapat memantik terjadinya konflik internal dan eksternal pada ranah kehidupan sosial. Ruh ajaran Islam yang diterapkan pada masa Rasulullah, yaitu ajaran rahmah li al-álamin nampak tenggelam oleh ambisi dan nafsu egoisme yang mereka kedepankan. ${ }^{6}$

Salah satu hadīth yang menjadi pijakan kaum fundamentalis yang ditengarai dapat menjadi pemicu munculnya radikalisme beragama adalah hadīth tentang larangan menyerupai budaya non Muslim (tashabbub). Cara berpakaian, bersosialisasi, hingga cara peribadatan yang dianggap sebagai sebuah keniscayaan dihindari

\footnotetext{
3 Sunnah Sirah adalah kebiasaan Rasulullah, yang meliputi urusan duniawi, seperti cara berdagang, kepemimpinan, dan lain sebagainya.

4 Sunnah Șürah adalah meliputi cara berpenampilan Rasulullah, seperti berpakaian, cara makan dan minum, cara tidur, dan lain sebagainya.

5 Sunnah Sarirah adalah meliputi akhlak dan prilaku Rasulullah, seperti cara bertutur kata, bersosialisasi dan bermasyarakat, menyikapi keburukan orang yang berbuat keji, dan lain sebagainya, lihat M. Ishaq Shahab, Khuruj Fi Sabilillab: Sarana Tarbiyah Umat untuk Membentuk Sifat Imaniyah (Bandung: Pustaka Ramadhan, 2007), 7.

${ }^{6}$ Hamim Ilyas, Fikih Akbar: Prinsip-Prinsip Teologis Islam Rabmatan Lil 'Alamin, ed. M. Iqbal Damawi (Ciputat: Pustaka Alvabet, 2018), 4-5.
} 
bahkan dijauhi, sehingga nampak perbedaan yang mencolok, baik pada ranah spritual maupun sosial.

Secara geografis Bangsa Arab sebagai sasaran turun dan dipraktikkannya wahyu memiliki budaya dan tradisi tersendiri namun tidak sekaya tradisi dan budaya yang dimiliki oleh Negara Indonesia (Nusantara), yang dikenal sebagai negara yang masyarakatnya sangat majemuk dan heterogen, yang memiliki berbagai macam jenis budaya dan tradisi yang kaya dengan nuansa kreativitas seni. Artinya, persoalan yang dihadapi oleh masyara-katnya tentu berbeda dengan negara-negara lain yang juga penduduknya menganut ajaran Islam, seperti Timur Tengah (negara-negara Arab), ${ }^{7}$ sehingga nampak diskriminatif jika konteks budaya Arab kemudian menjadi acuan satu-satunya sebagai cerminan budaya yang bersesuaian dengan ajaran Islam. Bila hal itu yang dipahami, maka ajaran Islam sebagai rabmah li al-älamin nampak sempit dan seolah tidak mengakui eksistensi dari keberagaman kreativitas manusia di berbagai belahan dunia, yang belum tentu berlawanan dengan ruh ajaran Islam yang dibawa oleh Rasulullah. ${ }^{8}$

Melalui fenomena tersebut, artikel ini bertujuan untuk merekonstruksi kembali pemahaman teks keagamaan, khususnya teks hadìth tentang larangan tashabbuh dengan menggunakan pendekatan sosio-historis, sehingga maqāsid al-nas dari pemaknaan hadīth tersebut dapat diimplementasikan di setiap masa yang kian kompleks dengan berbagai dinamika dan problematikanya. Fenomena semangat keberagamaan yang tumbuh di Nusantara kian dinamis, dan ajaran Islam yang fleksibel tetapi tidak keluar dari ruh ajaran Islam yang sälị̣ li kulli zamān wa makän. Dengan demikian, praktik ajaran agama sebagaimana dipraktikan oleh Rasulullah, tetap terimplementasi meski pada konteks yang berbeda, sehingga nilai-nilai dari ajaran agama Islam tidak hanya nampak secara simbolis, namun lebih mengedepankan spirit ajaran lita'ärafü (saling memahami) yang mampu memadukan antara spritualitas keagamaan dan hubungan sosial kemajemukan.

Kajian kontekstual seputar hadìth tashabbuh pada dasarnya telah banyak dilakukan oleh peneliti sebelumnya, di antaranya yang

\footnotetext{
7 Machasin, Memahami Islam dengan Ilmu Keadaban (Yogyakarta: Suka Press UIN Sunan Kalijaga, 2018), 16-17.

8 Fikria Najitama, "Artikel Pribumisasi Hukum Islam", Al-Mawarid: Jurnal Hukum Islam, Vol. 17, No. 1 (2007), 101-114.
} 
dilakukan oleh Mohd Anuar Ramli ${ }^{9}$ dan Ridwan Rosdiawan, ${ }^{10}$ yang banyak mengkaji tentang praktik tashabbuh menurut tinjauan praksis pada praktik keagamaan oleh masyarakat yang bermukim di daerah tertentu. Penelitian Azkiya Khikmatiar, ${ }^{11}$ Ade Wahidin, ${ }^{12}$ Juhra Muhammad Arib, ${ }^{13}$ dan Mohd Sulaiman Nuba, ${ }^{14}$ meninjau hadìth tentang tashabbuh dari berbagai perpektif teori dan tokoh tertentu. Kajian ini menggunakan data analisis kualitatif dengan pendekatan hermeneutik untuk menggali makna teks (linguistik), konteks (historis makro dan mikro), dan kontekstualisasi (signifikansi) tentang hadīth larangan tashabbuh, yang bertujuan untuk mengungkap sisi pemahaman dan penggunaan hadīth dalam konteks kekinian, khususnya bagi masyarakat Nusantara.

\section{Peran Hadīth sebagai Sumber Hukum}

Ulama klasik mendefinisikan hadīth sebagai segala hal yang mencakup perkataan, perbuatan, ketetapan, dan keadaan Rasulullah. ${ }^{15}$ Menurut Fazlur Rahman, hadīth diriwayatkan dalam bentuk pernyataan historis yang bersifat singular, ${ }^{16}$ yang pada dasarnya tidak mendeskripsikan secara menyeluruh tentang kondisi atau keadaan utuh kejadian pada generasi awal Islam. Maka secara historis, sesungguhnya periwayatan hadīth yang dilakukan oleh para sahabat

9 Mohd Anuar Ramli, "Fenomena Al-Tasyabbuh (Penyerupaan) dalam Sambutan Perayaan Masyarakat Majmuk di Malaysia", Jurnal Syariah, Vol. 21, No. 1 (2013), 21-42.

${ }^{10}$ Ridwan Rosdiawan and Septi Dwitasari, "Trend Perayaan Tahun Baru di Kota Pontianak: Perspektif Kegelisahan Seorang Remaja Muslimah", Al-Hikmab: Jurnal Dakwah, Vol. 9, No. 1 (2015), 109-122.

11 Azkiya Khikmatiar, "Reinterpretasi Ḥadīth Tasyabbuh: Aplikasi Teori Double Movement Fazlur Rahman dalam Memahami Hadīth", Journal of Hadits Studies, Vol. 1, No. 1 (2018), 31-42.

12 Ade Wahidin, "Tinjauan dan Hukum Tasyabbuh Perspektif Empat Imam Mazhab”, Al Mashlabah, Vol. 6, No. 1 (2018), 49-72.

13 Juhra Muhammad Arib, "Ucapan Selamat Natal Menurut Quraish Shihab dalam Tafsir Al Misbah: Studi Analisis terhadap Q.S. Maryam Ayat 33”, Aqlam: Journal of Islam and Plurality, Vol. 1, No. 2 (2018), 11-21.

14 Mohd Sulaiman Nuba, Mohd Anuar Ramli, and Mohd Farhan Md. Arifin, "Ibn Taimiyyah's View of Al-Tasyabbuh: Analysis of The Book Iqtida' Al-Sirat Al-Mustaqim Li Mukhalafati Ashab Al-Jahim", Online Journal of Research in Islamic Studies, Vol. 3, No. 1 (2016), 15-27.

${ }^{15}$ Nūr al-Dīn 'Itr, Manhaj al-Naqd fì 'Ulūm al-Hadìth (Beirut: Dār al-Fikr, 1992).

16 Syamsul Anwar, Paradigma Pemikiran Hadith Modern; Dalam Wacana Suatu Hadith Kontemporer (Yogyakarta: PT. Tiara Wacana, 2002), 157. 
bukanlah usaha terencana dalam bentuk sistematis, melainkan periwayatan tersebut mengalir sesuai kebutuhan umat pada generasi awal Islam. ${ }^{17}$ Pada perkembangannya, cakupan hadīth semakin meluas dan para ulama mengklasifisikannya berdasarkan sumber, sehingga hadīth bukan hanya bersumber dari Rasulullah, melainkan ijtihad sahabat dan täbiìn juga digolongkan sebagai hadīth, namun berbeda dalam penisbatan istilah dari jenis ḥdìth tersebut. Hadīth yang disandarkan kepada Rasulullah, disebut ḥdīth marfü', bila disandarkan kepada sahabat disebut hadis mawqüf, dan bila disandarkan kepada täbi în maka disebut hạadìth maqtū $\cdot^{\cdot 18}$

Periwayatan hadis dari masa ke masa (baca: tabaqät) berbeda dengan bentuk periwayatan al-Qur'ān yang diriwayatkan bi al-laf: (teks). Hadīth mengalami kelonggaran dengan dibolehkannya periwayatan menggunakan bi al-ma'nā (makna), sehingga kondisi tersebut dapat mempengaruhi nilai keotentikan periwayatan hadīth. Inilah sebabnya mengapa para kritikus hadìth ketika menilai sebuah riwayat hadīth, selain menguji kredibilitas sanad-nya, juga menelaah kesahihan matn-nya, yaitu apakah terdapat $i d r a ̈ j$ (penyisipan), 'illah, dan shudhüdh (cacat). ${ }^{19}$ Problematika tersebut yang kemudian membuat hadīth menghadapi berbagai kendala serius ketika hendak dijadikan acuan sebagai sumber hukum, sebab dibutuhkan kajian mendalam baik dari sisi keabsahan sanad dan matn-nya sebelum melanjutkan pada kajian signifikansi makna yang tekandung di dalamnya.

Berbagai teori telah dikembangkan dalam kajian kritik hadis, mulai ulama salaf (klasik), khalaf (modern), bahkan orientalis pun ikut terlibat dalam kajian diskursus naqd al-hadith, yang hal tersebut tidak terlepas dari problematika historis yang dihadapi oleh periwayatan hadīth itu sendiri. Salah seorang cendikiawan Muslim yang secara aktif terlibat dalam kajian kritik hadīth adalah Fazlur Rahman dengan teorinya double movement dan evolusi Sunnah, yang dikenal sangat bagus dalam mengkaji sisi historis periwayatan

\footnotetext{
17 Fazlur Rahman, "Methodology in History", Islamic Studies, Vol. 1, No. 2 (1962), 1-36.

18 Muhammad Zuhri, Hadith Nabi: Telaah Historis dan Metodologis (Yogyakarta: PT. Tiara Wacana, 1997), 8.

19 Kamaruddin Amin, Menguji Kembali Keakuratan Metode Kritik Hadith, cet. 1 (Jakarta: Hikmah, 2009), 56-60.
} 
hadīth. Menurut Fazlur Rahman, pada masa generasi awal Islam (sahābah) umat Islam menggunakan dua sumber hukum, yaitu alQur'ān dan hadìth dengan sangat dinamis dan historis. Mereka menyaksikan dan mengalami secara lansung problematika yang terjadi, sehingga mudah saja bagi mereka untuk menyesuaikan antara masalah yang dihadapi dan eksistensi al-Qur'ān dan hạaīth sebagai sumber hukum yang dapat menyelesaikan masalah yang muncul saat itu. Namun berbeda halnya ketika beranjak pada generasi selanjutnya (abad kedua dan ketiga Hijrìyah), yang mulai terjadi evolusi pemikiran agama yang nampak kaku, normatif, dan formalistik, sehingga posisi hadīth dijadikan sebagai sumber hukum yang paten tanpa mempertimbangkan sisi historis yang dinamis. Maka tidak heran bila hadīth hanya dipahami secara tekstual dengan menggunakan kajian pendekatan bahasa yang mendalam. ${ }^{20}$

Fazlur Rahman dalam kajiannya mencoba untuk membedakan antara hạaìth dan Sunnah. Menurutnya, hadìth merupakan verbalisasi dari konsep Sunnah, sedangkan Sunnah merupakan sebuah gambaran perilaku yang bersifat situasional dan substansial, baik secara moral, psikologis, dan material. Oleh karena itu, Sunnah dalam perkembangannya membutuhkan interpretasi dan adaptasi terhadap kondisi sosial yang dihadapinya (evolusi Sunnah) di setiap zaman dan tempat yang berbeda, sehingga Sunnah lebih cenderung dipahami sebagai acuan tauladan, bukan sebagai bentuk verbal yang mentah secara mutlak untuk dijadikan sebagai landasan hukum. ${ }^{21}$

\section{Redaksi Hadīth tentang Larangan Tashabbuh.}

Bila merujuk pada kitab hadith mu'tabarah (rujukan pokok), maka terdapat beberapa riwayat hadīth dengan varian matn atau teks yang berbeda-beda tetang larangan tashabbuh. Penulis mengklasifikasi redaksi hadīth berdasarkan tinjauan konteks hadīth, walaupun di antaranya ada yang menggunakan diksi tashabbuh secara lansung, dan ada pula yang menggunakan diksi perumpa-

\footnotetext{
${ }^{20}$ Safiuddin Puhri Qudsy and Ali Imron, Model-Model Penelitian Hadith Kontemporer (Yogyakarta: Pustaka Pelajar, 2013), 76.

21 Ma'mun, "Hadīth dan Sunnah dalam Perspektif Fazlur Rahman", Riwayah, Vol. 1, No. 2 (2015), 311-330.
} 
maan. Berikut redaksi hạdīth tentang larangan tashabbuh dalam hal umum:

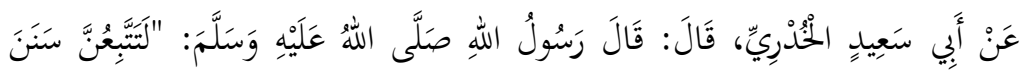

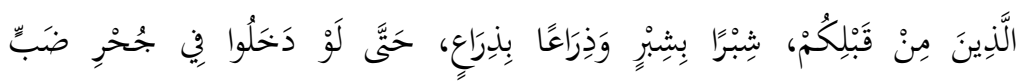

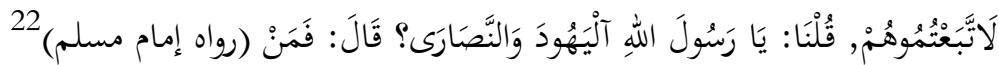

"Sesungguhnya kalian akan mengikuti jalan orang-orang sebelum kalian, sejengkal demi sejengkal dan sehasta demi sehasta sampai jika orang-orang yang kalian ikuti itu masuk ke lubang yang sempit, pasti kalian pun akan mengikutinya. Kami kemudian bertanya: 'Ya Rasulullah, apakah yang Anda maksud adalah orang Yahudi dan orang Nashrani?’ Beliau menjawab: 'siapa lagi??" (H.R. Muslim).

Larangan tashabbuh dalam hal ibadah ritual:

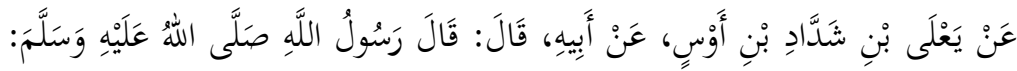

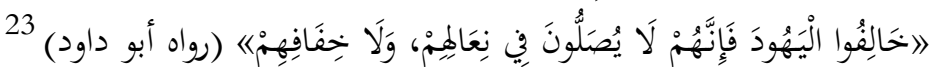

"Selisihilah kaum Yahudi karena sesungguhnya mereka tidak pernah salat dengan memakai sandal mereka dan tidak pula dengan khuf mereka" (H.R. Abū Dawūd).

Larangan tashabbuh dalam hal sosial-muamalah:

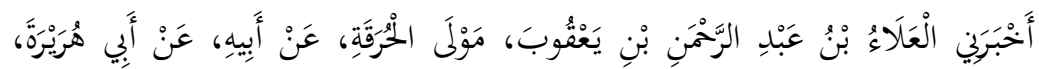

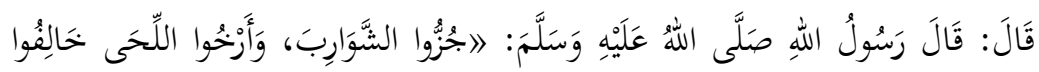

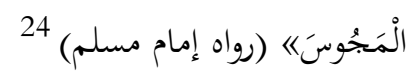

"Cukur kumis dan panjangkan jenggot dan selisihilah orangorang Majusi” (H.R. Muslim).

Sementara hadìth larangan tashabbuh dalam hal politik yaitu:

\footnotetext{
${ }^{22}$ Muslim b. Hajjāj al-Naysābūrī, Saḥịh Muslim, ed. Muḥammad Fu'ād 'Abd alBāqī, Vol. 4 (Beirut: Dār Iḥyā’ al-Turāth al-'Arabī, t.th.), 2054.

23 Abū Dawūd Sulaymān b. al-Ash'ath al-Sijistānī, Sunan Abì Dawūd, Vol. I (Beirut: Dār al-Kutub Risālat al-'Ilmīyah, 2009), 176.

24 al-Naysābūrī, Saḥị̣ Muslim, Vol. 2, 222.
} 


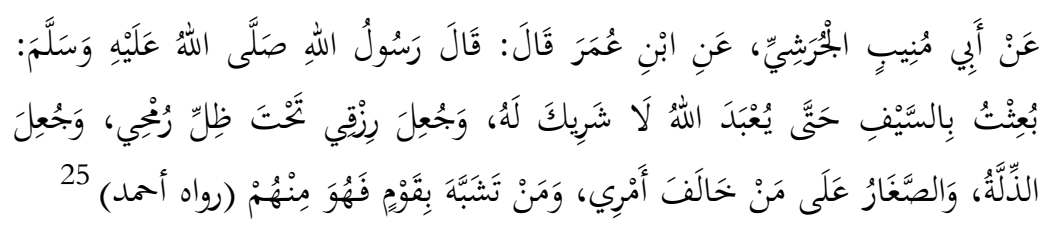

"Aku diutus dengan pedang, hingga manusia menyembah Allah, dan tidak ada yang menyekutukan-Nya. Dan dijadikan rezekiku di bawah naungan tombakku, dan dijadikan kehinaan dan kerendahan itu bagi orang yang menyelisihi perintahku. Barang siapa menyerupai suatu kaum, maka ia termasuk bagian dari kaum tersebut" (H.R. Aḥmad).

Sebenarnya masih banyak redaksi hadīth serupa yang penulis tidak cantumkan pada artikel ini, dengan asumsi bahwa redaksi hadìth masih serupa dengan redaksi yang penulis kutip dalam artikel ini. Para pengkaji dan kritikus hadīth berbeda dalam menyikapi status hadīth di atas, utamanya pada kajian isnad hadīth (kesahihan jalur periwayatan), di antaranya ada yang menganggap bahwa jalur periwayatan hadis tersebut bermasalah (da $i f),{ }^{26}$ sebagian lagi menganggap bahwa banyaknya periwayatan hadis yang sama dengan substansi makna yang serupa, sehingga dapat menguatkan antara satu dengan yang lainnya (hasan saḥị̆ lighayrih). ${ }^{27}$ Namun penulis tidak akan membahas perdebatan tersebut, dan tidak ingin menganalisis status $s a h i ̣ h$ atau tidaknya hadīth tersebut, melainkan hanya ingin fokus pada kajian makna substansi matn hadìth dengan mengkaji secara teks, konteks, dan kontekstualisasi menggunakan pendekatan sosio-historis dan makna signifikansinya, sehingga hadìth tersebut tidak hanya dipahami sebagai teks yang hidup pada masa Rasulullah, namun tidak dapat beradaptasi dan berinteraksi pada era kekinian.

\section{Makna Teks, Konteks, dan Signifikansi Hadīth tentang Larangan Tashabbuh}

Secara tekstual, kata tashabbuh berasal dari bahasa Arab shabaha yang berarti menyerupai sesuatu dari segi bentuk, warna, sifat, dan karakter, ia juga biasa disebut dengan istilah shibh, shabah, dan

\footnotetext{
${ }^{25}$ Ibid., Vol. 4, 516.

${ }^{26}$ Al-Sijistānī, Sunan Abì Dawūd, Vol. 6, 144.

27 Ibid.
} 
shābih. ${ }^{28}$ Menurut Ibn Manẓūr di dalam kitab Lisān al-'Arab, tashabbaha berarti sesuatu yang menyerupai atau menyamai dengan sesuatu yang lainnya. ${ }^{29}$ Adapun secara operasional, kata tashabbuh adalah penyerupaan seseorang terhadap orang lain baik dari segi perilaku, penampilan, tindak-tanduk, dan lain sebagainya dengan tujuan tertentu berdasarkan niatnya. ${ }^{30}$

Dari definisi di atas, maka dapat dipahami bahwa istilah tashabbuh berkonotasi pada makna penyerupaan yang dilakukan oleh seseorang dalam berbagai bentuk, warna, dan sifat dengan tujuan tertentu. Bila dikaitkan di dalam praktik keberagamaan, maka tashabbuh erat kaitannya dengan perilaku akidah, ibadah, dan muamalah yang dapat meliputi keyakinan, praktik ibadah, pakaian, penampilan, cara, waktu, dan tempat beribadah, yang dapat ditentukan berdasarkan niat pelakunya.

Bila ditinjau secara sepintas tentang makna literal tashabbuh yang kemudian dikaitkan dengan makna literal hadìth tersebut di atas, nampak mengisyaratkan tentang larangan Rasulullah, untuk mengikuti atau menyerupai perilaku kaum tertentu (non-Muslim), utamanya kaum Yahudi, Nasrani, Majusi, dan lain sebagainya. ${ }^{31}$ Dewasa ini, berbagai kalangan memahami hadīth tentang tashabbuh sebagai bentuk dalil yang melegitimasi larangan untuk menyerupai segala hal dari perilaku dan praktik, baik dalam bentuk ibadah maupun muamalah yang dilakukan oleh non-Muslim. Bahkan hingga jenis pakaian, ciri fisik menjadi ciri khas Muslim zaman milenial, sedangkan yang berbeda dengannya dianggap tidak menjalankan Sunnah Nabi, bahkan cenderung dianggap melakukan tashabbuh yang berimplikasi pada iman dan justifikasi ḅudūd (hukuman takfiri atau penghuni neraka). Di sini perlu ditegaskan sekali lagi, bahwa hal itu diakibatkan oleh cara pemahaman hạdīth yang bersifat tekstual-literal semata, dan menutup keinginan untuk

\footnotetext{
${ }^{28}$ Aḥmad b. Fāris b. Zakariyyā, Mu'jam Maqāyìs al-Lughah, Vol. 3 (Beirut: Dār alJayl, 1411), 243.

29 Muḥammad b. Mukrim b. 'Alī al-Ifrikī, Lisān al-'Arab, Vol. 2 (Beirut: Dār Sadr, 1414), 494.

30 Jamīl Habīb al-Luwayhiq, al-Tashabbuh al-Manhì 'anh Fì al-Fiqh al-Islāmì (Mekah: Jāmi'at Umm al-Qurā \& Wizārat Ta'līm 'Alī, 1417), 20.

31 Zayn al-Dīn Muḥammad al-Qāhirī, al-Taysìr bi Sharh al-Jāmi al-Saghìr, Vol. 2 (Riyadh: Maktabah Imām al-Shāfi $(\overline{1}, 1988), 410$.
} 
mengkaji secara historis dan signifikansi dari konteks ḥdith yang berkembang saat itu.

Dengan slogan "hijrah" dan "back to al-Qur'an and Sunnab" yang digembar-gemborkan oleh beberapa kelompok fundamentalis, seolah ingin melepaskan diri dari modernitas zaman dan menarik diri untuk kembali hidup sesuai kondisi zaman Rasulullah 1400-an tahun yang lalu. Bahkan, hal tersebut dianggap sebagai bentuk keniscayaan, demi mengembalikan peradaban Islam pada masa kejayaan seperti sedia kala. Pandangan tersebut tentu saja menyalahi dinamika perubahan zaman yang telah menjadi sunnat Allāh (ketetapan Allah), sebab ajaran Islam pada dasarnya bukan untuk menghindari dinamika tersebut, melainkan bagaimana seseorang mampu menyikapi perubahan zaman yang dinamis dengan tetap berpegang teguh pada nilai-nilai ajaran Islam, bukan pada bentuk tekstualnya.

Jika hadīth tersebut dikaji secara historis pada masa Rasulullah, persoalan yang muncul adalah apa yang melatarbelakangi pelarangan tersebut? Apakah yang dimaksud oleh Rasulullah, adalah segala prilaku, termasuk di dalamnya ibadah dan muamalah? Adakah batasan-batasan tertentu dari larangan tashabbub? Apakah budaya yang berkembang saat itu dapat mempengaruhi dakwah yang diajarkan oleh Rasulullah? Apakah pengaruh budaya jāhilīyah, Yahudi, Nasrani, dan Majusi dapat merusak tatanan keimanan atau akidah monoteisme (tauhid) kala itu? Untuk menjawab pertanyaanpertanyaan tersebut, tentu tidak hanya cukup dengan menggunakan kajian tekstual-literal semata, melainkan perlu dilakukan kajian secara meluas dan konprehensif, utamanya terkait konteks yang terjadi pada masa Rasulullah, kala mengucapkan hạīith tersebut, sehingga dapatlah dipahami maksud dari tujuan Rasulullah, mengucapkan larangan tashabbuh kepada umatnya saat itu, bukan hanya secara mikro, melainkan perlu juga kiranya untuk dikaji dan dianalisis secara makro, dengan tujuan untuk menemukan gap budaya yang berkembang saat itu, yang dianggap berbeda secara signifikan dengan ajaran Islam yang diajarkan oleh Rasulullah kepada umatnya.

\section{Konteks Historis secara Makro}

Bangsa Arab sebelum datangnya Islam dikenal sebagai bangsa jahiliyah (kebodohan), disebut sebagai bangsa jahiliyah bukan karena mereka buta huruf, melainkan yang dimaksud adalah 
ketidaktahuan mereka tentang eksistensi Tuhan yang sesungguhnya, mereka menganggap bahwa benda-benda yang mereka buat sendiri dapat dijadikan sesembahan yang termanifestasi sebagai Tuhan (paganisme), selain itu, penindasan, kesewenang-wenangan, saling merendahkan, antikemanusiaan, dan perbudakan, mewarnai kehidupan bangsa Arab kala itu, mereka yang memiliki harta kekayaan merupakan level strata sosial tertinggi yang kemudian memegang kendali kekuasaan. ${ }^{32}$ Rasulullah, pernah mengungkapkan hal tersebut melalui riwayat dari Muslim dan Bukhārī:

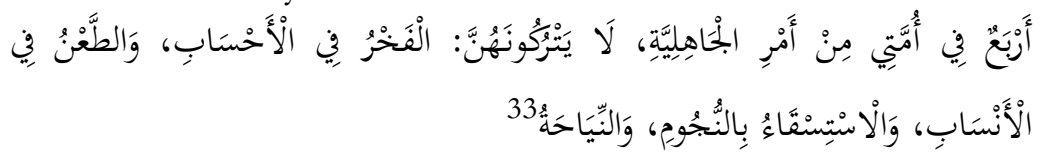

"Empat hal kebiasaan kaum jahiliyah yang sulit bagi mereka untuk meninggalkannya, yaitu mencela nasab, menyombongkan keturunan, meratapi mayit, dan memohon kepada bintang untuk diturunkan hujan".

Di dalam riwayat lain secara tegas disebutkan tentang peringatan Rasulullah kepada umat yang telah beriman kala itu untuk tidak terjebak kembali kepada kebiasaan jahiliyah mereka, berikut redaksi hadīthnya:

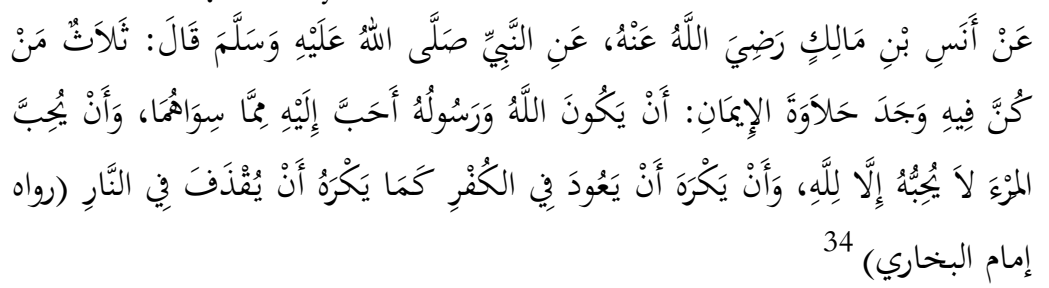

"Seseorang tidak akan pernah mendapatkan manisnya iman sehingga ia tidakmencintai seseorang kecuali karena Allah; sehingga dilemparkan ke dalam api lebih ia sukai dari pada kembali kepada kekufuran setelah Allah selamatkan darinya; sehingga Allah dan Rasul-Nya lebih ia cintai daripada selainnya" (H.R. Bukhārī).

Ungkapan tersebut tentu saja merupakan bentuk kegelisahan yang dihadapi oleh Rasulullah pada periode Mekah, sehingga target

\footnotetext{
32 Abdul Sattar, "Respons Nabi terhadap Tradisi Jahiliyyah: Studi Reportase Hadīth Nabi”, THEOLOGIA, Vol. 28, No. 1 (2017), 183-206.

33 Al-Naysābūrī, Saḩ̄̄h Muslim, Vol. 2, 644.

${ }^{34}$ Al-Bukhārī, Șaḥị̣ al-Imām Bukhārì., Vol. 1, 12.
} 
utamanya pada masa awal menyampaikan risalah ajaran Islam adalah untuk menghapus kebiasaan tersebut, dengan memperkenalkan keyakinan monoteis (tauhid), dan saling menghargai dan menyayangi sesama makhluk sosial yang bertolak belakang dengan keyakinan jahiliyah pada masa itu.

Usaha yang dilakukan oleh Rasulullah tentu saja mendapatkan tantangan yang berat dan penolakan yang keras dari kaum jahiliyah, sebab tradisi turun-temurun yang telah diwariskan oleh leluhur, digugat dengan hadirnya ajaran baru yang dibawa olehnya, yang tiada lain adalah keturunan dan keluarga dekat mereka sendiri. ${ }^{35}$ Bahkan mereka tidak segan-segan untuk melakukan penindasan hingga percobaan pembunuhan akibat ajakan untuk meninggalkan ajaran nenek moyang mereka yang terus masif dilakukan oleh Rasulullah dan pengikutnya. Kondisi yang demikian terus berlanjut hingga Rasulullah mengambil keputusan untuk hijrah meninggalkan Mekah menuju Madinah yang lebih menjanjikan dalam menerima ajaran Islam. ${ }^{36}$

Pada saat Rasulullah di Madinah, nampaknya ajaran Islam lebih mudah diterima oleh penduduk setempat. Ini disebabkan karena sebagian penduduk Madinah telah memeluk agama samāwì (Yahudi dan Nasrani) yang monoteis, sehingga tidak sedikit di antara penganut agama Yahudi dan Nasrani yang akhirnya memeluk ajaran yang dibawa oleh Rasulullah. ${ }^{37}$ Namun demikian, bukan berarti Rasulullah tidak mendapatkan tekanan dan gangguan dari penduduk Madinah, bahkan kerap kali orang-orang Yahudi dan Nasrani mencoba untuk melemahkan keyakinan umat Islam kala $\mathrm{itu}^{38}$ sebagaimana tawaran mereka kepada umat Islam yang disinggung oleh Allah di dalam al-Qur'ān sebagai berikut:

\footnotetext{
35 Mubasyaroh, "Karakteristik dan Strategi Dakwah Rasulullah Muhammad Saw pada Periode Makkah," at-Tabsyir: Journal of Islamic Broadcasting Communication, Vol. 3, No. 2 (2015), 383-404.

${ }^{36}$ Munzir Suparto and Harjani Hefni, Metode Dakwah (Jakarta: Prenada Media, 2003), 48.

37 Ira M. Lapidus, Sejarah Sosial Umat Islam, terj. Ghufron A. Mas'adi (Jakarta: Raja Grafindo Persada, 1999). 38.

38 A Syalabi, Sejarah dan Kebudayaan Islam I (Jakarta: Pustaka Al-Husna, 2003). 104.
} 


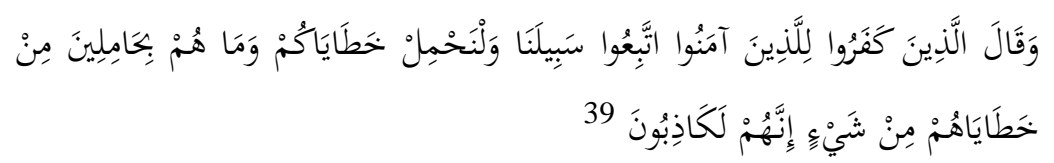

"Orang-orang kafir itu berkata kepada orang-orang yang telah beriman, Wahai orang-orang mukmin, ikutilah cara hidup kami. Kami akan menanggung segala dosa kalian selama kalian mengikuti kami'. Padahal sebenarnya orang-orang kafir itu tidak sedikit pun sanggup menanggung dosa-dosa mereka sendiri. Sungguh orang-orang kafir itu termasuk golongan pendusta".

Oleh karena itu, pada periode Madinah, mayoritas ayat-ayat alQur'ān yang diwahyukan kepada Rasulullah berorientasi untuk menguatkan iman mereka kepada Allah melalui ibadah dan amalamal saleh. Hal tersebut ditandai dengan redaksi ayat "yā ayyuha alladhina ämanü", yang kemudian diikuti dengan perintah melaksanakan ibadah dan amal saleh, dan termasuk pula di dalamnya penekanan perbedaan secara signifikan antara ajaran Islam dan ajaran agama samām Madinah. Hal itu untuk memperkuat agama Islam sebagai penyempurna terhadap ajaran sebelumnya, sebagaimana firman Allah di dalam Q.S. al-Baqarah:

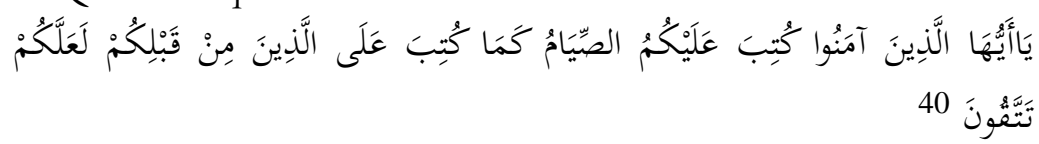

"Wahai orang-orang yang beriman, telah ditetapkan kepada kalian perintah untuk melaksanakan ibadah puasa, sebagaimana yang demikian itu telah perintahkan pula kepada umat-umat sebelum kalian, agar kalian menjadi hamba yang bertakwa".

Dari uraian di atas dapat dipahami bahwa budaya dan tradisi jahiliyah yang dianut oleh bangsa Arab khususnya di Kota Mekah dan sekitarnya sebelum datangnya Islam telah mendarah daging dan sulit untuk ditinggalkan. Hal ini berbeda dengan penduduk Madinah yang sebagian penduduknya telah memeluk agama samāwi, sehingga telah terbentuk akidah ketuhanan monoteis, walaupun dianggap telah mengalami penyimpangan. Hadirnya sosok Rasulullah telah membawa risalah tauhid yang paham dan

\footnotetext{
${ }^{39}$ Q.S. al-'Ankabūt [29]: 12.

${ }^{40}$ Q.S. al-Baqarah [2]: 183.
} 
ajarannya berlawanan dengan sebelumnya. Oleh karena itu, perjuangan dakwah Rasulullah untuk mengubah paham sebelumnya sangat berat, dan Rasulullah senantiasa mengingatkan kepada umatnya untuk tidak terjebak kembali pada paham-paham yang bertentangan dengan nilai-nilai intisari dari ajaran tauhid, sehingga keimanan mereka tidak mudah tergoyahkan.

\section{Konteks Historis secara Mikro}

'Alī b. Muhammad di dalam kitabnya, Mirqāt al-Mafätīh Sharh Mishqät al-Mashäbih, menjelaskan tentang riwayat "man tashabbah bi qawmin fa buwa minhum". Menurut al-Nawawī yang menukil ungkapan 'Abd Allāh b. Mubārak, bahwa ungkapan tersebut dikhususkan hanya pada masa Rasulullah. Pada konteks peperangan yang terjadi kala itu, Rasulullah, menegaskan tetang hukum dan tujuan jihad (perang). ${ }^{41}$ Maka dapat dipahami, bahwa bisa jadi ungkapan tersebut dikhususkan pada konteks strategi peperangan yang diajarkan oleh Rasulullah kepada umatnya, agar ketika mereka dalam peperangan tidak bertujuan untuk sekadar membunuh, melainkan untuk mengajak musuh-musuh mereka menyembah Allah dan tidak menyekutukan-Nya, sehingga bila musuh tersebut bertaubat dan mengucapkan syahadat, maka dilarang untuk membunuhnya.

Hal tersebut sejalan dengan riwayat Muslim yang menukil hadìth tentang riwayat salah seorang sahabat bernama 'Usāmah b. Zayd, yang ketika di medan perang ia membunuh salah seorang musuhnya yang sempat mengucapkan kalimat syahadat. Kejadian tersebut kemudian diceritakan kepada Rasulullah, lalu Rasulullah bertanya kepada 'Usāmah b. Zayd, "Apakah engkau tetap membunuhnya?", pertanyaan tersebut terus diulangi oleh Rasulullah, sebagai bentuk penekanan atas ketidaksetujuannya terhadap prilaku tersebut, kemudian 'Usāmah menjawab, "wahai Rasulullah, sesungguhnya orang itu mengucapkan kalimat syahadat hanya karena takut kepada pedang saya". Lalu Rasulullah bertanya dengan nada yang tegas kepada 'Usāmah, "apakah engkau telah

\footnotetext{
41 'Alī b. Muḥammad al-Qārī, Mir'at al-Mafätīḥ Sharḥ Mishqat al-Masāäḥ̣, Vol. 6 (Beirut: Dār al-Fikr, 2002), 2470.
} 
membelah dadanya, sehingga engkau tau ia mengucapkannya dengan sungguh-sungguh atau tidak?". ${ }^{42}$

Kisah tersebut menunjukkan bahwa strategi perang yang diajarkan oleh Rasulullah kepada umatnya berbeda dengan strategi peperangan orang-orang kafir. Ungkapan tersebut ingin menegaskan bahwa barang siapa yang berperang dengan tujuan untuk membunuh secara sadis, maka ia sama halnya seperti sifat orangorang kafir yang mengingkari rahmat Allah. Oleh karena itu, bila hạaīth tersebut dijadikan dasar legitimasi sebagai larangan menyerupai orang-orang Yahudi dan Nasrani dalam segala aspek, maka sungguh hal tersebut telah keluar dari konteks hadìth yang sesungguhnya.

Adapun makna tashabbuh di dalam konteks hadith yang telah penulis uraikan di atas, berdasarkan tinjauan historis secara makro dan mikro, dapat dipahami bahwa Rasulullah melarang perilaku tashabbuh pada konteks tertentu yang telah menjadi ciri khas utama bagi kaum non-Muslim pada masa itu. Artinya bahwa terdapat gap signifikan yang menjadi ciri khas dari ajaran Islam yang dibawa Rasulullah dengan berbagai ajaran dan paham yang tumbuh pada era Mekah, Madinah dan sekitarnya.

Namun bila ditinjau lebih spesifik, tashabbuh yang digambarkan di dalam berbagai riwayat hadīth tidak berlaku secara umum, melainkan terdapat hal-hal tertentu sebagai penekanan Rasulullah kepada umatnya kala itu, sebab bisa saja dengan melakukan tashabbuh, sulit untuk dibedakan antara umat yang telah beriman dan mereka yang masih pada keyakinan jahiliyah, Majusi, Yahudi, atau Nasrani. Penekanan tersebut dilakukan oleh Rasulullah agar kebiasaan lama mereka terhadap paham belum mampu mereka bedakan dengan ajaran Islam yang di bawa oleh Rasulullah baik dari segi peribadatan, hubungan sosial, politik, ekonomi, bahkan strategi perang yang dianggap memiliki tujuan dan maksud yang berbeda.

Dalam beberapa kasus, kerap kali Rasulullah menunjukkan kepada umatnya perilaku tertentu yang diadopsi dari ritus ibadah, budaya, dan tradisi yang telah tumbuh pada masa itu, namun kemudian dilakukan islamisasi oleh Rasulullah. Di antara ritus

${ }^{42}$ Muslim b. Hạjāià al-Naysābūrī, Șậih Muslim, ed. Muḥammad Fu'ād 'Abd alBāqī, Vol. 1 (Beirut: Dār a-Ihyyā’ al-Turāth, t.th.), 96. 
ibadah yang diadopsi adalah ibadah haji, umrah, memuliakan ka'bah, berkumpul pada hari Jum'at, puasa, dan lain sebagainya. ${ }^{43}$ Salah satu contoh adalah puasa adalah puasa sunnah yawm 'A Ashürä' (hari 'Ásyūrä', 10 Muharram) oleh orang-orang Yahudi Madinah kala itu, dan Rasulullah kemudian memerintahkan kepada umatnya untuk melaksanakan hal yang serupa namun dengan cara yang berbeda, sebagaimana yang disebutkan di dalam riwayat hadīth berikut:

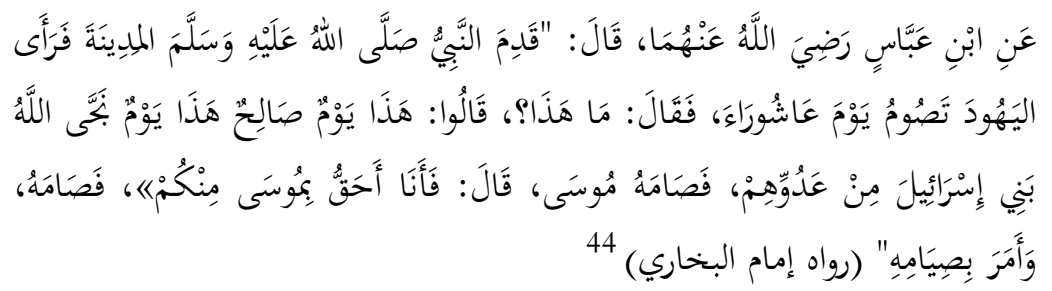

"Dari Ibn 'Abbās radiyallāh 'anhumā, beliau berkata: 'Ketika Rasulullah, tiba di Madinah, Beliau mendapati orang-orang Yahudi melaksanakan ibadah puasa 'Áshürā'. Kemudian Rasulullah, bertanya, 'apa yang kalian lakukan?' Mereka menjawab, 'Ini adalah hari yang sangat mulia. Ini adalah hari di mana Allah menyelamatkan Musa dan kaumnya. Ketika itu pula Fir'aun dan kaumnya ditenggelamkan. Musa berpuasa pada hari ini dalam rangka bersyukur, maka kami pun mengikuti beliau berpuasa pada hari ini'. Rasulullah lalu bersabda, 'Kita seharusnya lebih berhak dan lebih utama mengikuti Musa daripada kalian'. Lalu setelah itu Rasulullah, memerintahkan kaum Muslimin untuk berpuasa" (H.R. Bukhārī).

Riwayat tersebut menunjukkan bahwa Rasulullah melaksanakan ibadah sebagaimana yang dilakukan oleh orang-orang Yahudi saat itu, namun dalam hal ini Rasulullah kemudian mengislamisasi ibadah Yahudi tersebut li tajdid al-niyah (memperbarui niat), sematamata melaksanakan ibadah sebagai bentuk penghormatan kepada nabi-nabi sebelumnya, dan sebagai bentuk rasa syukur atas nikmat Allah. Selain riwayat tersebut di atas, terdapat banyak penyerupaan (baca: Islamisasi) muamalah yang dilakukan oleh Rasulullah baik secara maupun secara komunal (umatnya pun diperintahkan).

43 Syaikhuddin, "Kearifan Dialogis Nabi Atas Tradisi Kultural Arab: Sebuah Tinjauan Hadīth”, ESENSLA: Jurnal Ilmu-Ilmu Ushuluddin, Vol. 13, No. 2 (2012), 187-202.

44 Al-Bukhārī, Șaḥ̣̄̄ al-Imām Bukhārì, Vol. 3, 44. 
Contoh ibadah yang bersifat individu adalah ungkapan 'Abd Allāh b. 'Abbās yang menggambarkan tentang kerapian sisiran rambut Rasulullah yang mengikuti orang-orang Yahudi, namun dengan ciri khas tertentu,

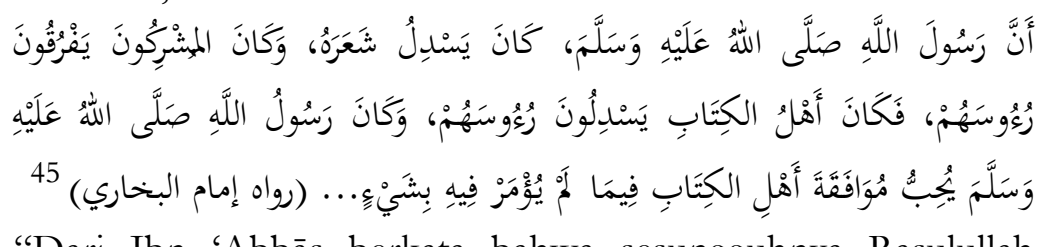

"Dari Ibn 'Abbās berkata bahwa sesungguhnya Rasulullah menjuntaikan rambutnya (merapikan), sedangkan orang-orang musyrik menyibakkan rambutnya, adapun abl al-kitäb (orangorang Yahudi) menjuntaikan rambut mereka, sesungguhnya Rasulullah lebih suka menyamakan diri dengan para abl al-kitäb pada hal-hal di luar dari urusan ibadah" (H.R. Bukhārī).

Sementara dalam bentuk komunal juga banyak dijumpai, di antaranya tradisi berkabung dan berkumpul ketika salah seorang di antara kerabat meninggal dunia. Dalam tradisi jahiliyah mereka berkumpul dan meratapi mayat secara histeris, bahkan sampai menyewa sekelompok orang untuk menunjukkan kedukaan yang mendalam. Namun tradisi tersebut oleh Islam direduksi, dengan tetap mengadopsi nilai sosial di dalamnya, dan menghilangkan nilai jahiliyah (ratapan histeris) yang dinilai berlebihan. Demikian halnya dengan pernikahan, yang masa jahiliyah telah dikenal sistem pernikahan untuk mengikat hubungan yang sah (ijäb qabūl) antara suami dan istri, jika terdapat berbagai bentuk pernikahan yang merendahkan martabat perempuan, sehingga Islam hadir dengan mengadopsi sistem pernikahan yang sah, dengan menghapus tradisi pernikahan yang merendahkan martabat perempuan, seperti membatasi jumlah istri dengan hanya maksimal empat orang. ${ }^{46}$

Dari uraian di atas, maka dapat dipahami bahwa terdapat berbagai tradisi dan budaya yang telah ada pada zaman jahiliyah di Mekah maupun di Madinah, yang oleh Rasulullah tidak serta merta dihilangkan, melainkan bila perkara itu dianggap ada ruang untuk menyisipkan nilai-nilai ajaran Islam di dalamnya, Rasulullah berusaha untuk melakukannya. Namun bila perkara itu erat kaitannya dengan akidah atau iman, maka Rasulullah secara tegas melarang-

\footnotetext{
45 Ibid., Vol. 4, 189.

${ }^{46}$ Syaikhuddin, "Kearifan Dialogis Nabi".
} 
nya. Maka berdasarkan hal ini, tidak semua perkara yang dilakukan oleh orang-orang jahiliyah maupun Yahudi kala itu menjadi hal yang harus ditinggalkan, melainkan ada usaha untuk mengislamisasikannya bila dianggap baik dan tidak merusak akidah umat.

\section{Kontektualisasi Hadīth Tashabbuh di Era Kekinian}

Sebagaimana yang telah diuraikan sebelumnya, bahwa pemahaman hadīth tidak hanya sebatas menyesuaikan kehidapan Rasulullah pada masanya, melainkan dibutuhkan pemahaman yang mendalam guna mendapatkan signifikansi tentang latar belakang hadīth tersebut diucapkan oleh Rasulullah atau dipraktekkan oleh generasi setelahnya. Alhasil hadīth tersebut tidak hanya hidup pada masa tertentu, melainkan dapat diterapkan di setiap zaman dan tempat yang berbeda sesuai konteks masyarakat yang dihadapinya. Oleh karena itu, guna menerapkan hadīth larangan tashabbuh pada era kekinian, khususnya pada konteks masyarakat Islam di Nusantara, maka perlu kiranya untuk mengetahui corak dari tradisi dan budaya masyarakat setempat, agar tidak menimbulkan kesenjangan hubungan antara ajaran agama dan budaya masyarakat lokal, terkhusus di Nusantara yang notabene memiliki kekayaan ragam budaya.

Tolhah Hasan mengutip pendapat al-Shāṭibī, mengklasifikasi tradisi kultural menjadi dua jenis, yaitu; (1) tradisi yang memiliki dalil shari berupa hukum wajib, sunnah, mubah, makruh, dan haram; (2) tradisi yang berlaku dalam budaya dan adat isitiadat masyarakat setempat yang tidak mendapatkan cakupan hukum oleh dalil shar i. Artinya, dalam konteks ini tidak terdapat perintah maupun larangan di dalamnya, sehingga lebih cenderung menyerahkan urusan tersebut kepada ketetapan adat ('urf) yang berlaku pada masyarakat setempat, tetapi tidak bertentangan dengan dalil shari ${ }^{i}$ yang lainnya. ${ }^{47}$

Dalam catatan sejarah masuknya Islam di Nusantara, disebutkan bahwa ajaran Islam dapat tumbuh dan berkembang karena para mubalig atau ulama yang membawa dan mengajarkan Islam pertama kali di Nusantara, menggunakan pendekatan Islamisasi tradisi dan budaya. Mereka tidak serta merta menyalahkan tradisi yeng telah ada dan tumbuh sebelumnya, melainkan

47 M. Tolhah Hasan, Ablussunnah wa al-Jama'ah: Dalam Persepsi dan Tradisi NU (Jakarta: Lantabora Press, 2006), 211. 
mereka berusaha untuk memadukan antara tradisi yang telah ada dengan menanamkan nilai-nilai ajaran Islam di dalamnya. Di sini tampak ajaran Islam sebagai agama yang menghargai kreativitas manusia dalam bentuk seni dan budaya, bukan untuk dibenci apalagi dijauhi, melainkan direduksi sesuai ajaran Islam, dengan menghilangkan hal-hal yang dianggap bertentangan dengan sharî́ah, dan menggiringnya kepada nilai-nilai yang lebih Islami. ${ }^{48}$

Salah satu tokoh penyebar Islam di Nusantara yang dikenal masif melakukan dakwah menggunakan pendekatan tersebut adalah Raden Syahid atau yang lebih dikenal dengan nama Sunan Kalijaga, ${ }^{49}$ metode dakwah yang digunakan dikenal dengan metode dakwah "sinkretisme". Salah satu implementasi dari metode tersebut yaitu memanfaatkan tradisi yang berkembang pada masanya untuk disisipkan nilai-nilai spritual agama, misalnya penggunaan wayang sebagai media dakwah yang notabene merupakan budaya Hindu-Buddha di pulau Jawa kala itu. Sunan Kalijaga kemudian mengelaborasi tradisi tersebut dengan menyisipkan pesan-pesan spritual agama (Islam) ketika menyampaikan kisah melalui media pewayangan tersebut. ${ }^{50}$

Walaupun pada mulanya metode dakwah tersebut menuai pro dan kontra di antara kalangan Walisongo sendiri, namun karena pertimbangan kemaslahatan umat saat itu, akhirnya metode tersebut dapat diterima oleh ulama, sehingga menuai hasil yang sangat signifikan terhadap perkembangan penyebaran agama Islam di Nusantara, khususnya di Jawa. ${ }^{51}$ Tentu saja bila merujuk pada pemahaman tekstual-litaral terhadap hadìth tentang larangan tashabbuh, maka apapun alasan hal semacam itu tidak dapat diterima. Akan tetapi, faktanya para ulama yang telah berhasil menyebarkan Islam di Nunsatara tanpa melalui kekerasan fisik (perang) tersebut tidak memahami demikian, melainkan mereka mencoba untuk menkontektualisasikan teks-teks agama sesuai

\footnotetext{
48 Hatmansyah, "Strategi dan Metode Dakwah Walisongo", al-Hiwar, Vol. 3, No. 5 (2015), 10-17.

49 Mark R. Woodward, Islam Jawa: Kesalehan Normatif versus Kebatinan, ed. Amiruddin (Yogyakarta: LKiS, 2004), 146.

50 Supriyanto Supriyanto, "Dakwah Sinkretis Sunan Kalijaga", KOMUNIKA: Jurnal Dakwah dan Komunikasi, Vol. 3, No. 1 (1970), 10-19.

${ }^{51}$ Hatmansyah, "Strategi dan Metode Dakwah Walisongo", 10-17.
} 
kebutuhan dan kemaslahatan umat saat itu. Pada dasarnya hal yang sama juga diterapkan oleh Rasulullah pada masa jahiliyah.

\section{Revitalisasi Hadīth Larangan Tashabbuh pada Era Kekinian}

Apabila hadīth larangan tashabbuh dikontekstualisasikan di era kekinian, maka dapat dipahami sebagai larangan tertentu kepada perilaku yang menyimpang dari nilai-nilai ajaran Islam, yang dapat mempengaruhi keimanan seseorang. Misalnya menggunakan simbol-simbol agama dengan tujuan untuk menghilangkan gap antara keyakinan satu agama dengan agama yang lainnya, atau sebagai bahan olokan atau penghinaan terhadap agama Islam atau agama yang lain, sehingga menimbulkan keresahan sosial, dan lebih cenderung mengarah kepada penistaan agama. Hal semacam ini jelas tidak dibolehkan, baik berdasarkan hukum sharī'ah maupun undang-undang positif yang berlaku di Indonesia, karena menyalahi nilai-nilai toleransi sosial dan agama. Namun bila hal itu dilakukan hanya karena untuk tujuan syiar semata, atau sebagai bentuk tradisi dan budaya yang tidak menyalahi ketentuan shari' ${ }^{-6}$ ah dan aturan agama yang lainnya, maka hal itu tentu tidak menjadi persoalan yang perlu dipermasalahkan. Hal tersebut sesuai dengan fatwa Majelis Ulama Indonesia (MUI) Nomor 56 Tahun 2016, tentang larangan menggunakan atribut keagamaan non-Muslim. ${ }^{52}$

Ketidakberlakuan tashabbuh bukan berarti harus mengikuti pola tradisi Arab sebagaimana yang dipraktikkan oleh Rasulullah, sebab hal tersebut tidak terlepas dari kondisi sosial di mana Rasulullah hidup dan bersosialisasi. Begitu pula sebaliknya, tidaklah dianggap tashabbuh bila seorang Muslim melakukan perilaku di luar dari tradisi Arab, baik dalam bentuk cara berpakaian, jenis pakaian, dan lain sebagainya, melainkan titik penekanan tashabbub adalah larangan terhadap perilaku yang bertentangan dengan nilai-nilai ajaran Islam yang erat kaitannya dengan akidah dan ibadah. Adapun pada persoalan muamalah, bila hal itu dianggap tidak menimbulkan penyimpangan akidah, keresahan dan konflik sosial setempat, maka tentu hal itu tidak dapat dianggap tashabbuh, karena Rasulullah sendiri menghargai hal yang demikian ketika bersosialisasi pada masa jahiliyah.

\footnotetext{
52 Majelis Ulama Indonesia, "Hukum Menggunakan Atribut Keagamaan NonMuslim”, Fatwa Nomor 16 Tahun 2016.
} 
Bila tashabbuh yang dimaksud adalah segala bentuk penyerupaan selain dari tradisi sosial yang pernah dilakukan oleh Rasulullah, maka umat Islam tidak akan mampu keluar dari keterpurukan dan akan sulit untuk berkembang. Hal ini menyebabkan pembahasan dan kajian yang berkembang di dalam pengkajian Islam hanya berkutat pada persoalan teologi semata, dan yang lebih mirisnya, hanya sibuk untuk mempermasalahkan urusan furü 'iyah yang debatable terhadap perkara yang tidak akan pernah selesai sejak masa klasik hingga saat ini. Bahkan, terdapat kecenderungan menjadi biang perselisihan, sehingga nampak sulit untuk membedakan antara perbedaan dan perselisihan. Padahal, perbedaan adalah hal yang lumrah, yang berimplikasi pada sikap saling menghargai, sedangkan perselisihan hanya berorientasi pada pengklaiman yang berujung penyalahan dan konflik. Para ulama telah menetapkan bahwa perbedaan furü 'iyah bukanlah sesuatu yang mesti diperselisihkan, sebagaimana ungkapan Rashīd Riḍā:

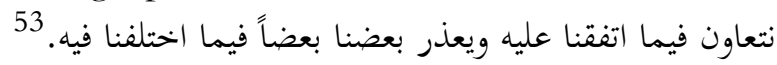

"Mari kita melaksanakan perkara yang kita sepakati, dan saling menghormati perkara yang kita beda di dalamnya".

Dari uraian di atas maka melalui artikel ini, penulis merumuskan ruang lingkup jenis tashabbuh ada dua, yaitu tashabbub yang terkait persoalan teologis-normatif dan tashabbuh terkait persolan sosial kemasyarakatan (muamalah). Adapun tashabbuh yang pertama meliputi: (1) Tashabbuh dalam bentuk akidah, misalkan mengadopsi keyakinan trinitas untuk diterapkan dalam akidah tauhid; (2) Tashabbuh dalam bentuk ibadah di mana jenis tashabbub ini dengan sengaja meniru ibadah agama lain dengan tujuan mencela atau mencampuradukan ibadah tanpa mendatangkan maslahat sosial atau bertentangan dengan aturan sharíah yang telah dibakukan oleh para ulama, misalnya shalat dengan membaca ayat Injil, dan lain sebagainya; (3) Tashabbuh dengan menggunakan simbol-simbol keagamaan, jenis ini menekankan pada penggunaan simbol agama yang menggiring pada bentuk penistaan agama, misalkan dengan sengaja menggunakan simbol agama tertentu sebagai propaganda atau menyebar berita hoax, atau misalnya umat Islam menggunakan kalung salib atau pakaian khas pendeta atau biarawati. Jenis

\footnotetext{
${ }^{3}$ Nāshir b. 'Abd Allāh b. 'Alī al-Qafarī, Mas'alabtal-Taqrīb bayn Abl al-Sunnah wa Shīah, Vol. 2 (Riyadh: Dār Ṭaybah li al-Nashr wa al-Tawzī', 1428), 228.
} 
tashabbuh tersebut dilarang karena dapat menimbulkan perilaku intoleransi dan menistakan agama tertentu.

Adapun tashabbuh dalam hal persoalan sosial meliputi: (1) Tashabbuh dalam bidang sistem ekonomi. Sistem ekonomi yang dimaksud berorientasi pada kemaslahatan pembangunan ekonomi umat dan tidak menimbulkan gharar (tipu daya); (2) Tashabbuh dalam bidang ilmu pengetahuan, di mana jenis tashabbub ini tentu saja sangat dianjurkan bila ilmu pengetahuan tersebut mendatangkan keuntungan bagi perkembangan paradigma dan sistem ilmu pengetahuan umat Islam, misalkan memadukan ilmu sains dan ilmu teologi (integrasi ilmu pengetahuan), atau menggunakan pendekatan hermeneutik untuk menafsirkan al-Qur'ān selama tidak bertentangan dengan kaidah dasar penafsiran yang telah ditetapkan oleh para ulama, atau orientasinya hanya sebatas untuk menyelami lebih dalam makna al-Qur'ān; (3) Tashabbuh dalam bidang politik, yang berorientasi pada kemaslahatan negara dan masyarakat, dengan tujuan mencapai kemakmuran dan keadilan sosial yang sejalan dengan nilai-nilai sharíah; (4) Tashabbub dalam bidang dakwah; jenis ini menekankan pada retorika, media, dan manajemen dakwah; (5) Tashabbuh dalam bidang manajemen, dengan mengadopsi sistem dan pola manajemen yang berorintasi pada integritas, profesionalitas, tanggung jawab, transparansi, dan inovasi; (6) Tashabbuh dalam bidang sosial budaya, dengan mengadopsi tradisi dan budaya lokal sebagai bagian dari adat istiadat masyarakat setempat untuk mendapatkan ruang kreativitas yang sejalan dengan nilai-nilai syarīah; (7) Tashabbuh dalam bidang seni, yang hal ini hampir sama dengan jenis tashabbuh sebelumnya, yaitu mengadopsi nilai seni yang Islami tanpa mencedarai norma-norma agama, dan masih banyak lagi bidang-bidang sosial yang lainnya. Pada prinsipnya, selama berorientasi pada kemaslahatan manusia dan berkesesuaian dengan norma-norma agama, maka tindakan tashabbuh tidak perlu dipermasalahkan, sebab tujuan agama selain sebagai orientasi spritualitas, termasuk juga di dalamnya untuk membentuk tatanan sosial yang sejahtera, tenteram, adil, berperadaban.

Pada akhirnya, penulis menganggap bahwa kekeliruan dalam memahami hadìth tentang larangan tashabbub dengan menggunakan pendekatan tekstualis-literal hanya dapat melahirnya keberagamaan yang jumud, dan terkesan menutup diri untuk beradaptasi dengan 
perkembangan zaman. Hal ini tampak pada agama yang hanya memiliki pengamalan simbolis, namun kering kerontang dengan nilai-nilai toleransi sosial, terlebih dapat mencabut ruh ajaran Islam yang săliḩ likulli zamān wa makān. Karenanya, diskursus pemahaman nas-nas agama dengan menggunakan pendekatan sosiohistoris berdasarkan teks, konteks, dan kontekstulisasi hendaknya terus digalakkan dan disosialisasikan. Hal ini bukan hanya pada tingkat akademisi, dalam hal ini perguruan tinggi, melainkan juga dapat mencakup kepada seluruh masyarakat luas, agar mereka tidak terjebak pada paham radikal, intoleran, dan sikap anarkis dalam menjalankan ajaran agama.

\section{Penutup}

Pemahaman tekstual terhadap hadith tentang larangan tashabbub merupakan biang fundamentalis-radikalis, sebab ketidakmampuan mereka menerima dinamika perubahan zaman dan perbedaan budaya lokal yang beragam. Selain itu, paham tersebut nampak mengkultuskan kelompok tertentu, sehingga lebih cenderung egois dalam mengklaim kebenaran yang dianggapnya absolut, serta lebih mudah untuk menyalahkan paham yang berseberangan dengan pendapat kelompok mereka. Oleh karena itu, pendekatan sosio-historis dalam memahami hadis secara teks, konteks, dan kontekstualisasi hendaknya diramu sehingga mudah untuk dipahami dan diimplementasikan bagi masyarakat luas, agar pemahaman terhadap agama tidak nampak jumud dan terkesan hanya menjadi milik kelompok tertentu.

Berdasarkan kajian historis makro maupun mikro, menunjukkan bahwa konteks hadīth tentang larangan tashabbub memiliki makna signifikan, yaitu secara normatif tujuannya adalah untuk menjaga dan memperkuat keimanan, serta mempertahankan akidah tauhid. Secara sosial kultural bertujuan untuk menunjukkan perilaku rạmah li al-álamin sebagai perwujudan toleransi dan menjunjung tinggi nilai-nilai kemanusian dan keadaban, demi menciptakan stabilitas keamanan dan kesejahteraan sosial masyarakat .

Aktualisasi Hadith tentang larangan tashabbuh berorientasi pada dua jenis yaitu; (1) Tashabbub dalam bentuk teologis-normatif, dalam hal ini mencakup akidah, ibadah, dan penggunaan simbolsimbol keagamaan. Di sini tidak dibenarkan melakukan tashabbuh dalam hal ini,sebab dapat merusak akidah tauhid sebagai ciri utama 
dari ajaran Islam; (2) Tashabbuh dalam bentuk sosial kemasyarakatan (muamalah), dalam hal ini tashabbub kepada non muslim tidak menjadi permasalahan bila output yang dihasilkan dapat mendatangkan maslahat bagi umat Islam dan kemanusiaan serta tidak bertentangan dengan pokok shari'at Islam, sehingga dapat mewujudkan keadilan, kemakmuran, dan kesejahteraan sesial, sebagai perwujudan Islam rạ̣mah li al-älamin.

\section{Daftar Rujukan}

Amin, Kamaruddin. Menguji Kembali Keakuratan Metode Kritik Hadith, cet. 1. Jakarta: Hikmah, 2009.

Anwar, Syamsul. Paradigma Pemikiran Hadith Modern; Dalam Wacana Suatu Hadith Kontemporer. Yogyakarta: PT Tiara Wacana, 2002.

Arib, Juhra Muhammad. "Ucapan Selamat Natal Menurut Quraish Shihab dalam Tafsir Al Misbah Studi Analisis terhadap Q.S. Maryam Ayat 33", Aqlam: Journal of Islam and Plurality, Vol. 1, No. 2, 2018.

Bukhārī (al), Muḥammad b. Ismāî̀l. Șaḥīh al-Imām Bukhārì, ed.

Muhammad Zuhayr b. Nāṣir al-Nāṣir, cet. I, 2002.

Fāris, Aḥmad. Mújam Maqayis Al-Lughah. Beirut: Dār al-Jayl, 1411.

Hasan, M. Tolhah. Ablussunnah Wal-Jama'ah: Dalam Persepsi dan Tradisi NU. Jakarta: Lantabora Press, 2006.

Hatmansyah. "Strategi Dan Metode Dakwah Walisongo", AlHiwar, Vol. 3, No. 5, 2015.

Mājah, Abū 'Abd Allāh Muḥammad b. Yazīd. Sunan Ibn Mäjah, cet. 1. Beirut: Dār al-Risālah al-'Ilmìyah, 2009.

Ifrīkī (al), Muhammad b. Mukrim b. 'Alī. Lisān al-'Arab. Beirut: Dār Șadr, 1414.

Ilyas, Hamim. Fikih Akbar: Prinsip-Prinsip Teologis Islam Rahmatan Lil 'Alamin, ed. M. Iqbal Damawi, cet. 1. Ciputat: Pustaka Alvabet, 2018.

Ilyasin, Muhammad. "Pencegahan Terorisme Melalui Tinjauan Agama dan Pendidikan", Jurnal Bimas Islam Kemenag RI, Vol. 6, No. 2, 2013.

Majelis Ulama Indonesia. "Hukum Menggunakan Atribut Keagamaan Non-Muslim”, Fatwa Nomor 16 Tahun 2016.

'Itr, Nūr al-Dīn. Manhaj al-Naqd Fì Ulüm al-Hadìth. Beirut: Dār alFikr, 1992. 
Khikmatiar, Azkiya. "Reinterpretasi Hadith Tashabbuh: Aplikasi Teori Double Movement Fazlur Rahman dalam Memahami Hadith", Journal of Hadits Studies, Vol. 1, No. 1, 2018.

Lapidus, Ira M. Sejarah Sosial Umat Islam, terj. Ghufron A. Mas'adi, Jakarta: Raja Grafindo Persada, 1999.

Luwayhiq (al), Jamīl Habīb. Al-Tashabbuh al-Manby 'anbu fì al-Fiqh al-Islāmi. Mekah: Jāmi'ah Umm al-Qurā \& Wizārat Ta'līm 'Alī, 1417.

Ma'mun. "Hadith dan Sunnah dalam Perspektif Fazlur Rahman", Riwayah, Vol. 1, No. 2, 2015.

Machasin. Memahami Islam dengan Ilmu Keadaban. Yogyakarta: Suka Press UIN Sunan Kalijaga, 2018.

Mubasyaroh. "Karakteristik dan Strategi Dakwah Rasulullah Muhammad pada Periode Makkah", at-Tabsyir: Journal of Broadcasting Communication, Vol. 3, No. 2, 2015.

Najitama, Fikria. "Artikel Pribumisasi Hukum Islam", Al-Mawarid, Vol. 17, No. 1, 2007.

Naysābūrī (al), Muslim b. Hạj)āj. Șaḥị̣ Muslim, ed. Muḥammad Fu'ād 'Abd al-Bāqī. Beirut: Dār Iḥyā' al-Turath al-'Arabī, t.th.

Nuba, Mohd Sulaiman, Mohd Anuar Ramli dan Mohd Farhan Md. Ariffin. "Ibn Taimiyyah's View of Al-Tashabbuh: Analysis of The Book Iqtida' al-Sirat al-Mustaqim Li Mukhalafati Ashab al-Jahim", Online Journal of Research in Islamic Studies, Vol. 3, No. 1, 2016.

Qafarī (al), Nāṣir b. 'Abd Allāh b. 'Alī. Mas'alat al-Taqrīb Bayn Abl Sunnah wa Shīah, cet. 3. Riyadh: Dār Ṭaybah li al-Nashr wa alTawzī', 1428.

Qāhirī (al), Zayn al-Dīn Muḥammad. al-Taysìr bi Sharḥ al-Jāmi‘ alSaghir. Riyadh: Maktabah Imām al-Shāfíī, 1988.

Qārī (al), 'Alī b. Muhammad. Mir'at al-Mafätīh Sharh Mishqāt alMașābīh, Vol. 6. Beirut: Dār al-Fikr, 2002.

Qudsy, Safiuddin Puhri dan Ali Imron. Model-Model Penelitian Hadith Kontemporer. Yogyakarta: Pustaka Pelajar, 2013.

Rahman, Fazlur. "Methodology in History", Islamic Studies, Vol. 1, No. 2, 1962.

Ramli, Mohd Anuar. "Fenomena Al-Tashabbuh (Penyerupaan) dalam Sambutan Perayaan Masyarakat Majmuk di Malaysia", Jurnal Syariah, Vol. 21, No. 1, 2013. 
Rosdiawan, Ridwan dan Septi Dwitasari. "Trend Perayaan Tahun Baru di Kota Pontianak: Perspektif Kegelisahan Seorang Remaja Muslimah", Al-Hikmah: Jurnal Dakwah, Vol. 9, No. 1, 2015.

Sattar, Abdul. "Respons Nabi terhadap Tradisi Jahiliyyah: Studi Reportase Hadith Nabi", TEOLOGLA, Vol. 28, No. 1, 2017.

Shahab, M. Ishaq. Khuruj Fi Sabilillah: Sarana Tarbiyah Umat untuk Membentuk Sifat Imaniyah. Bandung: Putaka Ramadhan, 2007.

Sijistānī (al), Abū Dawūd Sulayman b. al-Ash'ath. Sunan Abi Dawūd, cet. 1. Beirut: Dār al-Kutub Risālat al-'Ilmìyah, 2009.

Suparto, Munzir, and Harjani Hefni. Metode Dakwah. Jakarta: Prenada Media, 2003.

Supriyanto. "Dakwah Sinkretis Sunan Kalijaga", KOMUNIKA: Jurnal Dakwah dan Komunikasi, Vol. 3, No. 1, 1970.

Syaikhuddin. "Kearifan Dialogis Nabi atas Tradisi Kultural Arab:

Sebuah Tinjauan Hadith", ESENSIA: Jurnal Ilmu-Ilmu Ushuluddin, Vol. 13, No. 2, 2012.

Shaybānī (al), Abū 'Abd Allāh Aḥmad b. Muḥammad b. Ḥanbal. Musnad Imām Aḅmad Ibn Hanbal, ed. Aḥmad Muhammad Shākir. Kairo: Dār al-Hadīth, 1995.

Syalabi, A. Sejarah dan Kebudayaan Islam I. Jakarta: Pustaka AlHusna, 2003.

Ṭabrānī (al), Sulaymān b. Aḥmad b. Ayyūb. Al-Mu'jam al-Awsat, ed. Ṭāriq b. 'Awdhillāh b. Muhammad. Kairo: Dar Al-Haramain, t.th.

Tumanggor, Rusmin et al. Ilmu Sosial dan Budaya Dasar, Edisi Ketiga. Jakarta: Kencana, 2010.

Tirmidhī (al), Muhạammad b. 'Īsā. Al-Jāmi' Al-Kabir Sunan AlTirmidhì, ed. Bashar 'Awad Ma'rūf. Beirut: Dār al-Gharbī alIslāmī, 1998.

Wahidin, Ade. "Tinjauan dan Hukum Tashabbuh Perspektif Empat Imam Mazhab", Al-Mashlahah, Vol. 6, No. 1, 2018.

Woodward, Mark R. Islam Jawa: Kesalehan Normatif versus Kebatinan, ed. Amiruddin, cet. 2. Yogyakarta: LKiS, 2004.

Zuhri, Muhammad. Hadith Nabi: Telaah Historis dan Metodologis. Yogyakarta: PT. Tiara Wacana, 1997. 